\title{
Social Sciences in One Health: Insights From Multiple Worlds Perspectives on the Dam Rupture in Brumadinho-Brazil
}

\author{
Ana Pérola Drulla Brandão ${ }^{1 *}$, Stefanie Sussai ${ }^{2}$, Jéssica Alves de Lima Germine ${ }^{3}$, \\ Diego Duarte Eltz ${ }^{4}$ and Aline Araújo ${ }^{5}$
}

${ }^{1}$ Department of Preventive Medicine, Faculty of Medicine, University of São Paulo, São Paulo, Brazil, ${ }^{2}$ Department of Preventive Veterinary Medicine and Animal Health, Faculty of Veterinary Medicine and Animal Science, University of São Paulo, São Paulo, Brazil, ${ }^{3}$ Graduate Program in Human and Social Sciences, Federal University of ABC, Santo André, Brazil, ${ }^{4}$ Graduate Program in Social Anthropology, Federal University of Rio Grande do Sul, Porto Alegre, Brazil, ${ }^{5}$ Graduate Program in Social Sciences, University of Vale do Rio dos Sinos, São Leopoldo, Brazil

Concepts that integrate human, animal, and ecosystem health - such as One Health $(\mathrm{OH})$ - have been highlighted in recent years and mobilized in transdisciplinary approaches. However, there is a lack of input from the social sciences in $\mathrm{OH}$ discussions.

OPEN ACCESS

Edited by:

Christina Pettan-Brewer, University of Washington,

United States

Reviewed by:

Margot Winifred Parkes, University of Northern British Columbia Canada, Canada Nicole Redvers, University of North Dakota, United States

*Correspondence: Ana Pérola Drulla Brandão anaperola@alumni.usp.br

Specialty section:

This article was submitted to Planetary Health,

a section of the journal Frontiers in Public Health

Received: 04 January 2021 Accepted: 30 August 2021 Published: 29 September 2021

Citation:

Brandão APD, Sussai S, Germine JAL,

Eltz DD and Araújo A (2021) Social

Sciences in One Health: Insights From Multiple Worlds Perspectives on the Dam Rupture in Brumadinho-Brazil.

Front. Public Health 9:649355

doi: 10.3389/fpubh.2021.649355
This is a gap to overcome, including in Latin America. Therefore, this paper incorporates recent studies from economics and anthropology to the debate, contributing to the opening of transdisciplinary dialogues for the elaboration of $\mathrm{OH}$ theory and practice. As a starting point, we explore the recent case of a tailings dam breach, making considerations about how and why this event was experienced in different ways by the affected Indigenous and non-Indigenous worlds. From economics, we show how different theories perceive and impact these different worlds, presenting some existing alternatives to the hegemonic thinking of domination and exploitation. From anthropology, we present the perspectivism concept, deriving from the field of relational ontologies, suggesting there are significant and inevitable disagreements-equivocations-among different worlds. Thus, we discuss how the social sciences can help address challenging factors that need to be considered in health approaches that intend to deal with complex global problems. In conclusion, $\mathrm{OH}$ should incorporate social science discussions, considering relating practice to the multiple realities in which a particular problem or conflict is inserted. Overcoming the barriers that hinder transdisciplinary dialogue is fundamental and urgent for an effective approach to the multiple and distinct interconnections among humans, animals and environments.

Keywords: alternative economy, equivocations, extractivism, Indigenous worlds, one health, perspectivism, pluriverse, transdisciplinarity

\section{INTRODUCTION}

In recent years, some holistic health perspectives such as One Health, EcoHealth, and Planetary Health have grown in importance, and their concepts have undergone a process of constant refinement. Some differences between these terms have been studied and described, such as their origin and central focus, the sciences contributing to each of them, 
and how they value humans, animals and ecosystems (1). However, despite their differences, a common aspiration is toward integrative, collaborative, transdisciplinary, and multisectoral approaches that acknowledge the health of people, animals and the environment as "one" (2-7).

In common, such concepts also express a disagreement with the traditional Western thinking that radically separates and opposes nature and humanity. Thus, pairs of opposites like nature/humanity - among others derived from it, such as physical/metaphysical, objective/subjective, humanity/animality - has underpinned the way Western thinking understands nature (including animals) and relates to it, also reflecting how health and disease are differentiated. Therefore, the modern world winds up limiting entire ecosystems to an object, a resource to be controlled and managed to satisfy human needs.

This way of thinking led to what is conventionally called the Anthropocene (See Panel $\mathbf{1}$ for the glossary of terms used in this paper) (8). One of the factors that characterizes this new geological era is the expansion of mineral, oil and biotechnological extraction. These large-scale extractive activities have harmful impacts that are not homogeneously produced or distributed among the different strata of society. Besides, such impacts affect the health of people, animals and ecosystems $(9,10)$. Therefore, the effects of the Anthropocene on the planet are an issue to be considered by integrative health discussions (5).

Considering the holistic health perspectives, health and disease are no longer understood solely as qualities or conditions of an isolated individual - whether human or not - but rather, of a multispecies collective living in the Anthropocene epoch. From this assertion, it is clear that the social sciences can contribute to such health debates, since they focus on the interplay of humans, society, and nature.

Focusing on the One Health concept (Panel 1), early aspirations about the potential to address both social and ecological concerns have made landmarks and driven following studies since $(2,11)$. The significant role but also the underrepresentation of the social sciences have been described in recent years (12-14). Despite some initiatives, such as the efforts of the One Health Commission (15), this lack is still significant. Particularly in Brazil, the scientific publications using the term One Health have been mostly limited to the sphere of veterinary science and public health. This fact, which we consider to be a problem, is certainly multi-causal, but is also due to the strength of the disciplinary divisions that configure the scientific practices in the country.

With the paucity of social science perspectives within the One Health space, this current article therefore aims to contribute to the opening of transdisciplinary dialogues (Panel 1) in the elaboration of One Health theory and practice in Brazil - and in other Latin American countries that could benefit from this integration. Utilizing a particular event as an example and starting point, we present challenging factors (Panel 1) from studies and recent discussions in economics and anthropology that exemplify the need for transdisciplinary discourse.

\section{STARTING POINT: TAILINGS DAM RUPTURE IN BRUMADINHO, MINAS GERAIS STATE, BRAZIL}

In January 2019, a tailings dam operated by Vale S.A., the world's largest iron ore producer (16), collapsed in the municipality of Brumadinho. Nearly 13 million $\mathrm{m}^{3}$ of iron ore tailings (17) reached the tributaries of the Paraopeba River, part of the São Francisco Basin: one of the main watersheds in the country. The toxic mud traveled along the river, causing irreversible ecosystem damages, and affecting several other municipalities, including Indigenous territories such as the Pataxó Hã-hã-hãe and Kaxixó (18) (Figure 1). A total of 259 people died and 11 are still missing and assumed dead (19). The impacts of the tragedy are certainly far-reaching and long-lasting, and the socioenvironmental damages are systemic, synergistic, and dynamic, involving the health, environment, economics and rights of people, animals and affected areas $(20,21)$.

This tragedy occurred just 3 years after a similar one in the same region, in the municipality of Mariana, when another damco-owned by Vale-released 45 million $\mathrm{m}^{3}$ of iron ore tailings, reaching the tributaries of the Doce River and then the Atlantic Ocean. Since then, the company was aware of the risk of failure of the dam in Brumadinho, which means that the disaster was not natural and could have been avoided (17).

From this context and its consequences, we bring for reflection two very different statements about what happened. The first came from Vale's CEO: "Vale is a Brazilian jewel that cannot be condemned for an accident that happened in one of its dams, no matter how great its tragedy may have been" (22). The second one came from the Chief of the Naô Xohã village, where 25 Pataxó Huh-hã-hãe families lived: "It was a funeral without a wake. A piece of our body was cut off" (23).

These statements exemplify how and why events like this can be experienced and understood in different ways by the Indigenous and non-Indigenous worlds. For the mining company and the Brazilian government, the damage to the Paraopeba River represents an externality (Panel 1) that cannot compromise development. For the Pataxó Hã-hã-hãe Indigenous people, the river is not only what Western thinking understands as nature, but also a part of themselves - the watercourse is also a life course. Based on this context as a starting point, this paper relies on theories and discussions of economics and anthropology to suggest there are significant disagreements among multiple worlds (Panel 1).

\section{ECONOMICS: HOW DIFFERENT THEORIES PERCEIVE AND IMPACT MULTIPLE WORLDS}

In the statement by Vale's CEO, expressions such as "accident" and "cannot be punished," refer to the hegemonic economic thinking that treats environmental impacts as negative externalities. In this respect, externality refers to "side effects" arising from productive or consumption actions (24), that is, factors external to the system (25). In this case, the private 


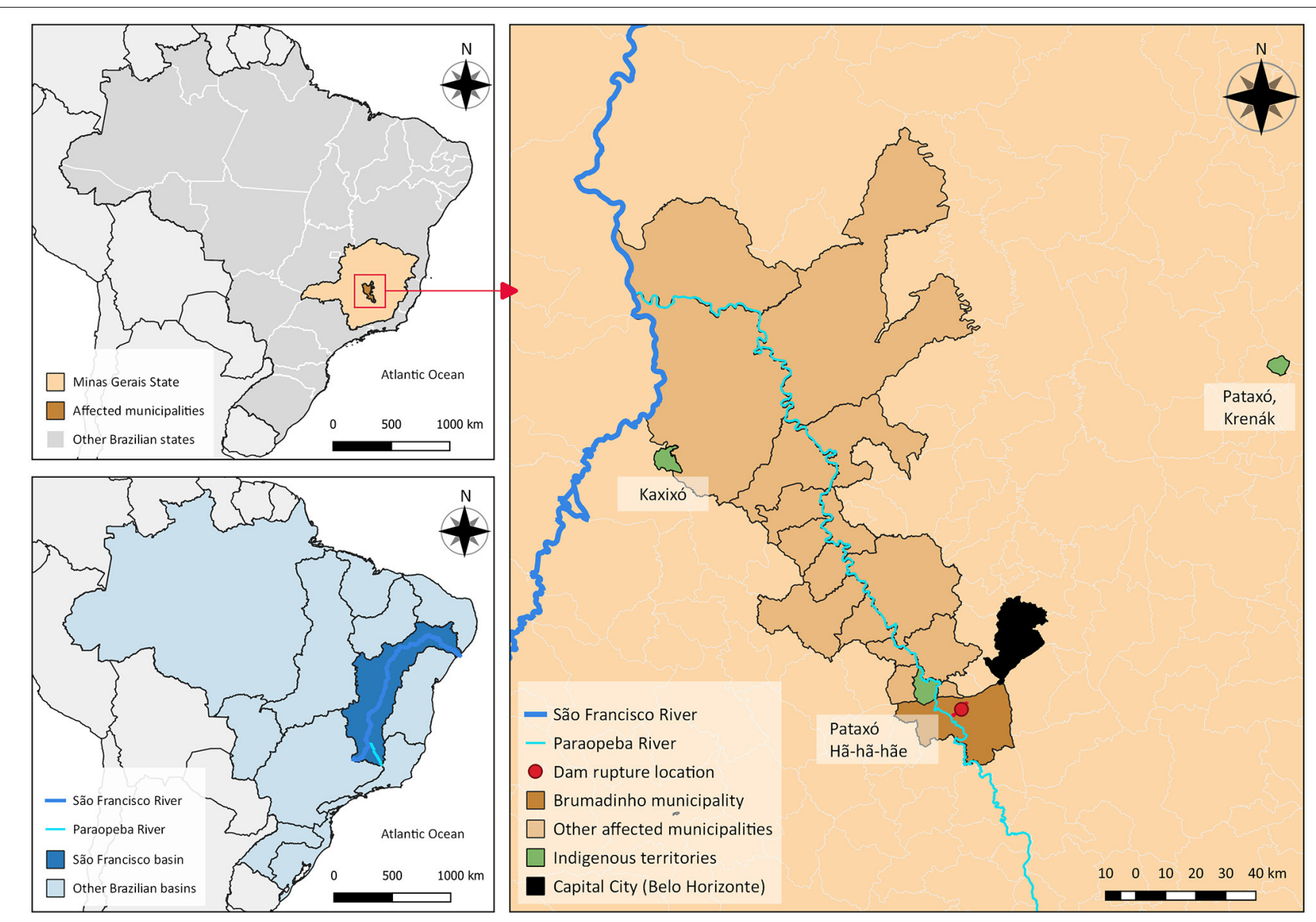

FIGURE 1 | Location of Brumadinho dam rupture, showing the extension of the impact on rivers, municipalities, and Indigenous territories.

benefits of the company's activities, measured in monetary terms, were prioritized to the detriment of the socio-environmental costs of the dam rupture, which cannot be precisely quantified.

In this productive system, the notion that "a river is a water pipe and animals are protein factories" (26) has become institutionalized. Since private property is a key element, the common goods - those shared by everyone and that do not belong to an individual or group, such as what is called natural resourcescan be 'managed' and tend to be overused, generating a negative externality to the environment or society.

For Vale, as well as for the entire economy derived from classical and neoclassical theories, the workable solutions offered to minimize such effects are limited to the creation of taxes and subsidies or some kind of "externality market." Then, in theory individuals can negotiate the costs derived from their activities $(25,27)$. Therefore, it is common for the mining, agriculture and tourism sectors to measure their impacts in monetary terms. However, it is impossible to attribute value to the lost lives, or to the socio-environmental impact caused - including the death of an entire river.

In this sense, two phenomena create and intensify the disastrous ecological scenario. The first is the dual and hierarchical perception of the world (such as human and nature). This is a way of justifying and legitimizing relations of domination, whether among humans or between humans and other-than-humans. The second is the fictions derived from traditional economics and imposed as absolute truths. These fictions are responsible for legitimizing and establishing economic fundamentalism as hegemonic, such as the idea that production is unrelated to life (26).

Alternative economic theories have emerged in opposition to the traditional ones and can enrich the dialogues with One Health since they question the idea that nature is just an object or resource. The political ecology focuses on socio-environmental conflicts, proposing the integration of indicators to broaden the view of the consequences of economic development in different populations and territories (28). The ecological economy contests the meaning of development and its implications, going beyond the concept of sustainable development and proposing an alternative to it. In addition, it presents multicriterial strategies allied with environmental policies to deal with such effects, such as the so-called externalities (29). The theories of degrowth presuppose a break with the production and consumption system based on capitalist domination and exploitation, through selflimitation and moderation (30), and abandonment of unlimited economic growth (31). 
In this direction, we cannot fail to mention the idea of buen vivir - good living - born in Latin America and influenced mainly by Andean and Amazonian Indigenous roots. Buen vivir is a plural concept conceived by the confluence of theoretical debates, Indigenous practices, social movements, and political constructions (32). Also, buen vivir questions the concept of wellbeing based on Eurocentric assumptions, defends overcoming the idea of development as a synonym for material accumulation, and offers alternatives to it $(33,34)$. The principles of buen vivir were formalized in the new Constitutions of Ecuador and Bolivia, as a fundamental base of the State.

Therefore, the alternative to the current scenario would be to overcome dualisms, admitting eco-dependence and interdependence, as well as placing life at the center of economics and politics (26), in order to build a possible non-domination system. In this sense, we introduce and explore a field of anthropology called relational ontologies (Panel 1), which shows that the dualistic ontology (that radically separates nature from humanity), despite its universal claim, is not the only one (35).

\section{ANTHROPOLOGY: WHEN ASSUMPTIONS ARE NOT COMMON - OR THE SAME - AMONG WORLDS}

The studies of relational ontologies concern the interrelationships of a broad community - considering community as a concept that "initially human-centered, is expanded to include other-than-humans" (35). Situating the practices of modernity in space and time, the relational ontologies demonstrate that not all worlds are made from the same divisions, such as human/other-than-human or culture/nature.

One example of relational ontology studies is perspectivism, formulated by Viveiros de Castro in 1996 (36). It has become one of the most cited concepts in Brazilian anthropology, and also is the most notable theoretical contribution to global anthropology (37). The term "perspectivism" comes from philosophy and was borrowed to highlight a striking aspect of Amerindian worlds: the way human beings see animals and other subjectivities is profoundly different from the way these beings see humans and themselves.

The notion of other-than-human beings having their own perspective comes from a great mythical division $(36,38,39)$ that is "shared by several, if not all, Indigenous people of the New World," as is stated by Viveiros de Castro (40). According to de Castro (41), unlike the Western evolutionary vulgate which uses soul and, more recently, consciousness or culture as criteria to distinguish humanity from animality - the Amerindian perspectivism states that the original condition of other-thanhuman beings is humanity, not animality. Their bodies, as we see them, are clothes that hide their internal human form, which is only visible to those of the same species or trans-specific beings, such as shamans. Thus, back in their homes - as the humans they are - they hunt, fish, fight, and perform rituals. If we start to see from their perspective, it means that our soul has been stolen or that we are being taken to a different world (41). ${ }^{1}$

The perspectivism discussion confronts the modernistic idea that there is only one shared world - one external and objective reality - and multiple representations of it, i.e., worldviews or cultures. The modern way of thinking enables cultures to be hierarchized according to how distant their representations are from that one reality. Such hierarchy allows a specific culture to have the privilege and monopoly of defining terms such as nature, culture, humanity, animality, health and disease (42). Instead, the perspectivism points to a pluriverse - multiple worlds that share the same culture, and even use the same terms, but differ according to the perspective of the referent, whether human or other-than-human. Thus, there is no privileged perspective to define reality.

Since these multiple worlds are not based on the same assumptions and divisions, there may be significant disagreements between them. In that respect, a category of perspectivism arises called equivocations (Panel 1), which emerges when different worlds use the same term to refer to different things. Because these equivocations are a result of a communicative relationship between different worlds, they express an ontological relationship and not an epistemic misconception (43).

We believe the Brumadinho catastrophe can illustrate an equivocation. As previously exemplified, for the Indigenous world, the Paraopeba River was a life course. This uncommon ${ }^{2}$ status of the river is unacceptable for the modern world. For Vale and the Brazilian State, a river is not - and cannot be different from a hydrographic formation, a formless universally shared common good that can be managed and exploited as an externality (44).

Since equivocations emanate from different worlds, they cannot be avoided. However, they can be controlled ${ }^{3}$ by a communicative exercise that considers the referential otherness of the different perspectives, maintaining and communicating their ontological differences $(45,46)$. This exercise invites us to think of a common alternative, namely "the expression of an ecology of divergent practices, constantly negotiating what would be their common interest" (44). Therefore, we suggest that identifying equivocations and being open to this communicative exercise can be a key element in any integrative health approach.

\footnotetext{
${ }^{1}$ In a classic illustration in this regard, Viveiros de Castro stated that jaguars, seeing themselves as humans, see humans as tapirs or wild pigs, so for them, our blood can be beer. If humans start to see the blood of his relatives as beer, taking the perspective of jaguars, this means that we are being taken to a different world to turn into a jaguar.

${ }^{2}$ The term "uncommon" - as used here - comes from the discussions of the anthropologist Marisol de la Cadena (44). In this context, the expression refers to a status of what is not universally shared, that is, of what is not the same among worlds.

${ }^{3}$ According to the anthropologist Eduardo Viveiros de Castro, in the perspectivism theory, to control an equivocation means to listen and speak knowing that the referents are different. That is, the difference between terms must be communicated and controlled in the dialogue. In symmetric humanity, to control equivocations is a way to preserve life (45).
} 


\section{DISCUSSION}

One Health professionals and researchers often address complex health phenomena and recognize the importance and need of integrating different fields of knowledge. The collaboration among disciplines can be imagined and carried out in diverse ways and with different objectives, as shown by the concepts of multi-, inter-, meta-, pluri- and transdisciplinarity (47-49). The last (and most complex) seeks knowledge between, through, and beyond disciplines, without a hierarchical relationship among them (50).

In Brazil, transdisciplinarity in health has advanced since the 1970's, with two historical movements that emerged in the context of fighting for democracy and against the military dictatorship that lasted from 1964 to 1985 . The first was the Brazilian Health Reform, resulting in the creation of the Unified Health System [SUS (Portuguese acronym)] (51). The second was the political-ideological-intellectual movement of Collective Health, resulting in a whole new field of health studies and practices (52). In the 1990's and 2000's, transdisciplinarity became more widespread after the SUS implemented its Family Health Strategy, with multi-professional teams working to promote health beyond the hospital environment (53).

However, in Brazil there are still many barriers that hinder knowledge sharing and unification, such as historical institutional structures, values and habits (54, 55). These obstacles, imposed by modernity, can manifest themselves as "social, pedagogical, ideological, political, psychological, methodological and technical" (54). Therefore, overcoming these barriers is a challenge additionally for professionals and researchers who seek to act within the realm of One Health.

Our starting point - the analysis of the dam rupture - provided elements that relate to some recent discussions in economics and anthropology. Such discussions are an example of the undeniable contribution of the social sciences to One Health issues, since they highlighted the existence of challenging factors - such as huge environmental impacts considered as mere externalities and the existence of equivocations between different worlds. These challenging factors need to be seriously considered by health approaches that intend to be integrative, since they increase the awareness of the complexity of health topics.

It is important to point out that the Brumadinho disaster is not an isolated event in Latin America. Other examples, just to cite a few, are the continuous oil spills in Ecuador (5658), environmental impacts of transgenics in Argentina (59), and disasters caused by mining in Chile (60). Such events and how they are usually managed show that the assumption that there is a passive, sacrificial and appropriate nature promotes huge pressure and impact on people, animals and ecosystems - especially on those in situations of vulnerability and living in countries with high social inequality (61).

Besides, the assumption that nature is an object to be sacrificed for human interests and needs reinforce and reiterate asymmetries, producing regimes of truth (Panel 1) and invalidations, that is, relegates other perspectives to a status of mere beliefs or metaphors (42). However, such assumption is neither natural nor cosmopolitan: it comes across the borders of other worlds, such as the Indigenous ones, which refuse to obey the mandate of the nature/humanity division and resist the imposed extractive projects (44). The point is: the communicative exercise between worlds is important to make sure that no regime of truth is reproduced and no world is neglected in the process of decision making on health problems that concern multiple worlds.

Since One Health is proposed to be transdisciplinary and approach increasingly complex global health challenges, its practice and scientific production should not reproduce regimes of truth and invalidations. On the contrary, One Health should be open to the idea that the multiplicity of interactions among humans, animals and ecosystems can be formed by different assumptions, linked not to cultural differences, but ontological ones. Therefore, One Health professionals and researchers should be aware of - and closer to - discussions of alternative economic theories along with the perspectivism and the debate of multiple worlds - especially those that conduct research in Latin America, due to the ongoing impact of the extractivism previously discussed. Thus, people involved in One Health can facilitate and participate in transdisciplinary dialogues, overcoming the disciplinary barriers that divide the scientific practices in their countries.

\section{CONCLUSION}

Considering the challenging factors exemplified by the Brumadinho dam failure under the economics and anthropology lenses, we suggest that to achieve their goals, researchers and practitioners using One Health approaches should incorporate discussions of alternative economic theories and the multiple worlds perspective. This would help to reduce the limited dualistic and anthropocentric views and regimes of truth. Moreover, we argue that One Health should always be related to the context of the realities - plural - in which a particular problem, conflict or challenge is inserted. This implies that One Health should be plural or have several versions.

Based on the discussion of extractivism, transdisciplinarity and contributions of the social sciences, we suggest that in Brazil - and other Latin American countries with a similar context - it is fundamental and urgent to overcome disciplinary barriers in One Health. That is, it is essential to include the social sciences and their professionals in One Health debates, for an effectively transdisciplinary dialogue about the multiple and distinct interconnections among humans, animals and ecosystems.

\section{DATA AVAILABILITY STATEMENT}

The original contributions presented in the study are included in the article/supplementary material, further inquiries can be directed to the corresponding authors.

\section{AUTHOR CONTRIBUTIONS}

$\mathrm{AB}$ and $\mathrm{AA}$ conceptualized the paper. $\mathrm{AB}$ and $\mathrm{SS}$ contributed to One Health and transdisciplinarity discussions. JG and AA contributed to the Economics discussions. AA and DE 
contributed to the Anthropology discussions. All authors contributed to the writing of the manuscript, read, edited, and approved the final manuscript.

\section{FUNDING}

Publication fee for this article was granted by a scholarship received from an anonymous donor of One Health Brasil.

\section{REFERENCES}

1. Lerner H, Berg C. A Comparison of three holistic approaches to health: one health, ecohealth, and planetary health. Front vet sci. (2017) 4:163. doi: $10.3389 /$ fvets. 2017.00163

2. Evans BR, Leighton FA. A history of one health. Rev Sci Tech. (2014) 33:41320. doi: 10.20506/rst.33.2.2298

3. Machalaba CC, Daszak P, Karesh WB, Shrivastava P. Future earth and ecohealth: a new paradigm toward global sustainability and health. Ecohealth. (2015) 12:553-4. doi: 10.1007/s10393-015-1076-6

4. Whitmee S, Haines A, Beyrer C, Boltz F, Capon AG, de Souza Dias $\mathrm{BF}$, et al. Safeguarding human health in the Anthropocene epoch: report of the rockefeller foundation-lancet commission on planetary health. Lancet. (2015) 386:1973-2028. doi: 10.1016/S0140-6736(15) 60901-1

5. Buse CG, Oestreicher JS, Ellis NR, Patrick R, Brisbois B, Jenkins AP, et al. Public health guide to field developments linking ecosystems, environments and health in the Anthropocene. J Epidemiol Community Health. (2018) 72:420-5. doi: 10.1136/jech-2017-210082

6. Harrison S, Kivuti-Bitok L, Macmillan A, Priest P. Ecohealth and one health: a theory-focused review in response to calls for convergence. Environ Int. (2019) 132:105058. doi: 10.1016/j.envint.2019.105058

7. Rüegg SR, Buttigieg SC, Goutard FL, Binot A, Morand S, Thys S, et al. Concepts and experiences in framing, integration and evaluation of one health and ecohealth. Front vet sci. (2019) 6:155. doi: 10.3389/fvets.2019.00155

8. Lewis SL, Maslin MA. Defining the Anthropocene. Nature. (2015) 519:17180. doi: $10.1038 /$ nature 14258

9. Brisbois BW. Mapping research on resource extraction and health: a scoping review. Extr Ind Soc. (2019) 6:250-9. doi: 10.1016/j.exis.2018.10.017

10. Moysés SJ, Soares RC. Planetary health in the Anthropocene. Health Promot Int. (2019) 34:i28-36. doi: 10.1093/heapro/daz012

11. Zinsstag J, Schelling E, Waltner-Toews D, Tanner M. From one medicine to one health and systemic approaches to health and well-being. Prev Vet Med. (2011) 101:148-56. doi: 10.1016/j.prevetmed.2010.07.003

12. Craddock S, Hinchliffe S. One world, one health? social science engagements with the one health agenda. Soc Sci Med. (2014) 129:1-4. doi: 10.1016/j.socscimed.2014.11.016

13. Lapinski MK, Funk JA, Moccia LT. Recommendations for the role of social science research in one health. Soc Sci Med. (2015) 129:5160. doi: 10.1016/j.socscimed.2014.09.048

14. Michalon, J. Accounting for one health: insights from the social sciences. Parasite. (2020) 27:56. doi: 10.1051/parasite/2020056

15. One Health Commission. Apex: One Health Comission c2021. One Health Social Sciences Initiative (2021). Available online at: https://www. onehealthcommission.org/en/programs/one_health_social_sciences_ initiative/ (Accessed Jan 4, 2021).

16. Darlington S, Glanz J, Andreoni M, Bloch M, Peçanha S, Singhvi A, et al. The New York Times:World. (2019). Available online at: https://www. nytimes.com/interactive/2019/02/09/world/americas/brazil-dam-collapse. html (Accessed Jan 4, 2021).

17. Brasil. Câmara dos Deputados. Comissão Parlamentar de Inquérito (CPI). Relatório: Rompimento da Barragem de Brumadinho [Report: Brumadinho Dam rupture]. Brasília (2019). p. 2287Portuguese.

18. Silva AA, Lunas DAL, Bicalho PSS, Maciel RMT. The impact of the Brumadinho dam rupture in Naô Xohâ village $=\mathrm{O}$ impacto do rompimento

\section{ACKNOWLEDGMENTS}

We would like to thank all the colleagues working in the transdisciplinary team of the Portal Saúde Única (freely translated as One Health Portal); which is a platform dedicated to disseminate, popularize, and promote the One Health concept in Brazil through the creation of digital content.

da barragem de Brumadinho na aldeia Naô Xohã. Sustentabilidade em Debate. (2019) 10:195-211. doi: 10.18472/SustDeb.v10n3.2019.24017

19. Vale: Brazil site S.A. Available online at: http://www.vale.com/brasil/ EN/aboutvale/reports/atualizacoes_brumadinho/Pages/updated-lists.aspx (Accessed Jan 4, 2021).

20. Polignano MV, Lemos RS. Rompimento da barragem da Vale em Brumadinho: impactos socioambientais na Bacia do Rio Paraopeba. Ciência e Cultura. (2020) 72:37-43. Portuguese. doi: 10.21800/2317-666020200002 00011

21. Rotta LHS, Alcântara E, Park E, Negri RG, Lin YN, Bernardo N et al. The 2019 brumadinho tailings dam collapse: possible cause and impacts of the worst human and environmental disaster in Brazil. Int J Appl Earth Obs Geoinf. (2020) 90:102119. doi: 10.1016/j.jag.2020.102119

22. Prazeres L. Vale é uma jóia e não pode ser condenada por Brumadinho, diz CEO da empresa. UOL:Cotidiano. (2019). Available online at: https://noticias. uol.com.br/cotidiano/ultimas-noticias/2019/02/14/vale-e-joia-nao-podeser-condenada-por-brumadinho-diz-presidente-da-empresa.htm (Accessed Jan 4, 2021).

23. Pinheiro M. Cortaram um pedaço do nosso corpo, diz cacique sobre Rio Paraopeba. Metrópoles:Brasil. (2019). Available online at: https://www. metropoles.com/brasil/cortaram-um-pedaco-do-nosso-corpo-diz-caciquesobre-rio-paraopeba (Accessed Jan 4, 2021).

24. Vasconcellos MAS. Economia: Micro e Macro. São Paulo: Ed. Atlas. (2011). p. 453.

25. Cavalcanti C. Conceptions of ecological economics: its relationship with mainstream and environmental economics = Concepções da economia ecológica: suas relações com a economia dominante e a economia ambiental. Estudos avançados. (2010) 24:53-67. doi: 10.1590/S0103-40142010000 100007

26. Herrero Y. Miradas ecofeministas para transitar a un mundo justo y sostenible. Revista de Economía Crítica. (2013) 16:278-307.

27. Hunt EK, Lautzenheiser M. História do pensamento econômico: uma perspectiva crítica [History of Economic Thought: a critical perspective]. 3rd ed. Villela AA, translator. Rio de Janeiro: Elsevier (2013). p. 504.

28. Porto MF, Martinez Alier J, Ecologia política, economia ecológica e saúde coletiva: interfaces para a sustentabilidade do desenvolvimento e para a promoção da saúde. [Political ecology, ecological economics, and public health: interfaces for the sustainability of development and health promotion]. Cad Saúde Pública. (2007) 23:S503-12. Portuguese. doi: 10.1590/S0102-311X20070016 00011

29. Martínez Alier J. O ecologismo dos pobres: conflitos ambientais e linguagens de valoração [Conflictos ambientales y lenguajes de valoración]. $2^{\text {nd }}$ ed. Waldman M, translator. São Paulo: Contexto (2014). Portuguese.

30. Azam G. In: Solón, P. Alternativas sistêmicas: Bem viver, decrescimento, comuns, ecofeminismo, direitos da mãe terra e desglobalização. São Paulo: Editora Elefante. (2019). Chapter 2, Decrescimento. p. 65-84. Portuguese.

31. Latouche S. Pequeno tratado do decrescimento sereno. 1st ed. São Paulo: WMF Martins Fontes (2009). p. 170. Portuguese.

32. Gudynas E, Acosta A. La renovación de la crítica al desarrollo y el buen vivir como alternativa. Utopía y praxis latinoamericana. (2011) 16:71-83. Spanish. Available online at: https://www.redalyc.org/articulo.oa?id=27919220007

33. Acosta A. O bem viver: uma oportunidade para imaginar outros mundos. São Paulo: Autonomia Literária. Editora Elefante (2019). p. 264. Portuguese. 
34. Chuji M, Rengifo G, Gudynas E. Buen vivir. In: Kothari A, Salleh A, Escobar A, Demaria F, Acosta A. Pluriverse - A Post-Development Dictionary. New Delhi: Tulika Books. Authors Upfront (2019). p. 111-4.

35. Escobar A. Territorios de diferencia: la ontología política de los derechos al territorio [territories of difference: political ontology of the rights to territory]. Cuadernos de Antropología Social. (2015) (41):25-38. doi: 10.5380/dma.v35i0.43540

36. Viveiros de Castro E. Os pronomes cosmológicos e o perspectivismo ameríndio. Mana. (1996) 22:115-44. Portuguese. [English version: Viveiros de Castro E. Cosmological deixis and amerindian perspectivism. J Royal anthropol Inst. (1998) 4:469-88]. doi: 10.1590/S0104-93131996000200005

37. Calavia Sáez O. Do perspectivismo ameríndio ao índio real [from amerindian perspectivism to the real indian]. Campos. (2012) 13:723. doi: $10.5380 /$ cam.v13i2.36728

38. Vanzolini M, Cesarino P. Perspectivism. In obo in Anthropology. Oxford University Press (2014). doi: 10.1093/obo/9780199766567-0083

39. Holbraad M, Pedersen MA. Natural relativism: Viveiros de Castro's perspectivism and multinaturalism. In: The Ontological Turn: An Anthropological Exposition. Cambridge: Cambridge University Press (2017). p. 157-98. doi: 10.1017/9781316218907

40. Viveiros de Castro E. Metafísicas canibais: elementos para uma antropologia pós-estrutural. [Métaphysiques cannibales: lignes d’anthropologie post-structurale]. $1^{\text {a }}$ ed. São Paulo: Cosac Naify (2015). Portuguese.

41. Viveiros de Castro E. A inconstância da Alma Selvagem e outros ensaios. São Paulo: Cosac Naify (2002). p. 552. Portuguese.

42. Blaser M. Storytelling Globalization from the Chaco and Beyond. Durham and London: Duke University Press (2010). P. 292. doi: 10.2307/j.ctv11cw0jf

43. Cadena $M$ de la. Natureza incomum: histórias do antropocego = Uncommoning nature: stories from the Anthroponot-seen. Revista do Instituto de Estudos Brasileiros. (2018) (69):95-117. doi: 10.11606/issn.2316-901X.v0i69p95-117

44. de la Cadena M. Protestando desde lo incomún. In: Santisteban RS, editor. Mujeres indígenas frente al cambio climático. Peru: Grupo Internacional de Trabajo sobre Asuntos Indígenas (2019). p. 35-48.

45. Viveiros de. Castro E. Perspectival anthropology and the method of controlled equivocation Tipití. J Soc Anthropol Lowland South America. (2004) 2:3-22. Available online at: https://digitalcommons.trinity.edu/tipiti/vol2/iss1/1/

46. Cadena M de la. Política indígena: un análisis más allá de la política. Red de antropologías del Mundo (RAM). (2008) 139-42. Available online at: http:// ram-wan.net/old/documents/05_e_Journal/journal-4/jwan4.pdf

47. Iribarry IN. Aproximações sobre a transdisciplinaridade: algumas linhas históricas, fundamentos e princípios aplicados ao trabalho de equipe [approaching transdisciplinarity: some historical lines, foundations and applied principles to team work]. Psicologia: reflexão e crítica. (2003) 16:48390. doi: 10.1590/S0102-79722003000300007

48. Almeida Filho ND. Transdisciplinaridade e o paradigma pós-disciplinar na saúde [transdisciplinarity and the post-disciplinary paradigm in health]. Saúde e Sociedade. (2005) 14:30-50. doi: 10.1590/S0104-12902005000300004

49. Nicolescu B. Transdisciplinarity: past, present and future. In: Haverkort B, Reijntjes C. Moving Worldviews: Reshaping Sciences, Policies And Practices For Endogenous Sustainable Development. Compas series on worldviews and sciences 4. Leusden: ETC/COMPAS. 2007. p. 142-66.

50. Nicolescu B. O Manifesto da Transdisciplinaridade [Manifesto Of Transdisciplinarity]. 3rd ed. Souza, LP, translator. São Paulo: Triom (2005). Portuguese.

51. Paim JS, Travassos CMR, Almeida CM, Bahia L, Macinko J. The Brazilian health system: history, advances, and challenges $=\mathrm{O}$ sistema de saúde brasileiro: história, avanços e desafios. Lancet. (2011) 377:177897. doi: 10.1016/S0140-6736(11)60054-8
52. Nunes ED. Saúde coletiva: história de uma ideia e de um conceito. Saúde e sociedade. (1994) 3:5-21. doi: 10.1590/S0104-129019940002 00002

53. Harris M, Haines A. Brazil's family health programme. BMJ. (2010) 341:c4945. doi: 10.1136/bmj.c4945

54. Feriotti ML. Equipe multiprofissional, transdisciplinaridade e saúde: desafios do nosso tempo. Vínculo-Revista do NESME. (2009) 6:179-93. Available online at: https://www.redalyc.org/articulo.oa?id=139422410007

55. Fonseca LEG. A transdisciplinaridade na educação superior. Outras palavras. (2016) 12. Portuguese. Available online at: http://revista.faculdadeprojecao. edu.br/index.php/Projecao5/article/view/670

56. Azevedo-Santos VM, Garcia-Ayala JR, Fearnside PM, Esteves FA, Pelicice FM, Laurance WF, et al. Amazon aquatic biodiversity imperiled by oil spills. Biodivers Conserv. (2016) 25:2831-4. doi: 10.1007/s10531-016-1 192-9

57. Maurice L, López F, Becerra S, Jamhoury H, Le Menach K, Dévier MH et al. Drinking water quality in areas impacted by oil activities in Ecuador: Associated health risks and social perception of human exposure. Science of The Total Environment. (2019) 690:1203-17. doi: 10.1016/j.scitotenv.2019. 07.089

58. Rivera-Parra JL, Vizcarra C, Mora K, Mayorga H, Dueñas JC. Spatial distribution of oil spills in the north eastern Ecuadorian Amazon: A comprehensive review of possible threats. Biol Conserv. (2020) 252:108820. doi: 10.1016/j.biocon.2020.108820

59. Lapegna P, Otero G. Cultivos transgénicos en América Latina: expropiación, valor negativo y Estado. Estudios Críticos del Desarrollo. 2016; 6(11):19-43. Spanish. doi: 10.35533/ecd.0611.pl.go

60. Compagnoni UM, Silva JC, Harzer JH. A complexidade e a gestão estratégica do resgate dos 33 mineiros soterrados na mina San Jose no Chile. Simpoi, anais. 2011. Portuguese.

61. Dias AO; Luz GS, Assunção VK, Gonçalves, TM. In: Ladwig NI, Schwalm H. Planejamento e gestão territorial: a sustentabilidade dos ecossistemas urbanos. Criciúma: EDIUNESC. 2018. Chapter 20: Mariana, o maior desastre ambiental do Brasil: uma análise do conflito socioambiental. p. 455-76. Portuguese. doi: 10.18616/pgt20

62. Blaser M, Cadena M de la. A World Of Many Worlds. Durham: Duke University Press (2018). Introduction: Pluriverse: Proposals For A World Of Many Worlds. p. 1-22. doi: 10.2307/j.ctv125jpzq.4

63. Foucault M. The Political Function of the Intellectual. Radical Philosophy. (1977) 17:12-4.

Conflict of Interest: The authors declare that the research was conducted in the absence of any commercial or financial relationships that could be construed as a potential conflict of interest.

Publisher's Note: All claims expressed in this article are solely those of the authors and do not necessarily represent those of their affiliated organizations, or those of the publisher, the editors and the reviewers. Any product that may be evaluated in this article, or claim that may be made by its manufacturer, is not guaranteed or endorsed by the publisher.

Copyright (C) 2021 Brandão, Sussai, Germine, Eltz and Araújo. This is an open-access article distributed under the terms of the Creative Commons Attribution License (CC $B Y)$. The use, distribution or reproduction in other forums is permitted, provided the original author(s) and the copyright owner(s) are credited and that the original publication in this journal is cited, in accordance with accepted academic practice. No use, distribution or reproduction is permitted which does not comply with these terms. 


\section{PANEL 1. GLOSSARY}

Anthropocene: It is an expression that designates a new era, subsequent to the Holocene, in which humanity has become a global geological force capable of changing the existence of systems and life forms on Earth (8).

Challenging factors: Important elements evidenced by the social sciences that, in a transdisciplinary context, increase the awareness of complexity of health topics. Such elements challenge the way health has been traditionally understood and practiced in the modern world. Challenging factors can be, for example: ontological differences; gender, racial or ethnic inequalities; religious or regional aspects (our definition).

Equivocation: Concept introduced by the anthropologist Eduardo Viveiros de Castro - in the Perspectivism theory that seeks to explain the mode of communication between Amerindian inhabitants (human and non-human) in the Brazilian Amazon. The term refers to the "referential alterity between homonymic concepts", or the "mode of communication par excellence between different perspectival positions" $(43,45)$. See more in section Anthropology: When Assumptions are not Common - or the Same - Among Worlds of this current article.

Externality: Benefits or costs arising from the production or consumption process that are not considered in the economic model (24).

Multiple worlds (pluriverse): Discussion that confronts the idea of modernity that there is only one world, proposing "a world of many worlds" or a world in which many different worlds can fit, such as the Indigenous and non-Indigenous worlds (62). See more in section Anthropology: When Assumptions are not Common - or the Same - Among Worlds of this current article.
One Health: A concept that acknowledge that the health of humans, animals, plants and ecosystems are deeply connected and therefore must be thought and worked together. For this, it is suggested the use of transdisciplinary and multisectoral health strategies and approaches (our definition).

Ontology: We use "ontology" as defined by Mario Blaser (2010) in three distinct - but not excluding - layers of meaning: 1. From sociology - "kinds of being and their relations"; 2. From science and technology - "ontologies are shaped through the practices and interactions of both human and nonhumans;" and 3. From his ethnographic work - "ontologies manifest as "stories" in which the assumptions of what kinds of things and relations make up a given world are readily graspable" (42).

Regimes of Truth: Concept introduced by Michel Foucault in 1975 defined as the "types of discourse it [society] harbours and causes to function as true; the mechanisms and instances which enable one to distinguish true from false statements, the way in which each is sanctioned; the techniques and procedures which are valorised for obtaining truth; the status of those who are charged with saying what counts as true" (63).

Transdisciplinarity: as the prefix "trans" indicates, it concerns what is - at the same time - between disciplines, trough the different disciplines and beyond any discipline. The aim of transdisciplinarity is the understanding of the present world(s), for which one of the imperatives is the unity of knowledge (50). 